\title{
PART XVI - STEREOSPECIFIC LIGANDS AND THEIR COMPLEXES SYNTHESIS, CHARACTERIZATION AND IN VITRO ANTIPROLIFERATIVE ACTIVITY OF NEW PLATINUM(IV) COMPLEXES WITH SOME $O, O^{\prime}$-DIALKYL ESTERS OF $(S, S)$-ETHYLENEDIAMINE- $N, N^{\prime}$-DI-2-PROPANOIC ACID AGAINST BREAST CANCER (MDA-MB-231) AND COLON CANCER (HCT-116 AND SW-480) CELL LINES
}

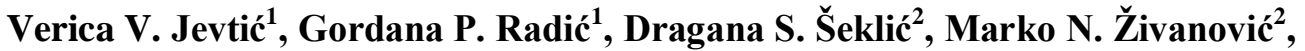 \\ Snežana D. Marković ${ }^{2}$, Srećko R. Trifunović ${ }^{1 *}$ \\ ${ }^{1}$ Department of Chemistry, Faculty of Science, University of Kragujevac, Radoja Domanovića 12, \\ 34000 Kragujevac, Republic of Serbia \\ ${ }^{2}$ Department of Biology and Ecology, Faculty of Science, University of Kragujevac, \\ Radoja Domanovića 12, 34000 Kragujevac, Republic of Serbia \\ srecko@kg.ac.rs
}

\begin{abstract}
Synthesis of four new platinum(IV) complexes (C1-C4) with bidentate $N, N^{\prime}$-ligand precursors, $O, O^{\prime}$-dialkyl esters (L1-L4) (alkyl = ethyl, propyl, butyl and pentyl) of $(S, S)$-ethylenediamine- $N, N^{\prime}$-di-2propanoic acid, $\mathrm{H}_{2}-S, S$-eddp were reported. The platinum(IV) complexes were characterized by elemental analysis and their structures determined on the basis of infra-red, ${ }^{1} \mathrm{H}$ and ${ }^{13} \mathrm{C}$ NMR spectroscopy. Cytotoxicity against human breast carcinoma MDA-MB-231, human colon carcinoma HCT-116 and SW-480 tumour cell lines was determined using the MTT assay, which indicated the larger the size of the complex or ligand, the greater the cytotoxicity.
\end{abstract}

Keywords: platinum(IV) complexes; $O, O^{\prime}$-dialkyl esters; antiproliferative activity; MTT test

\section{XVI ДЕЛ - СТЕРЕОСПЕЦИФИЧНИ ЛИГАНДИ И НИВНИ КОМПЛЕКСИ}

СИНТЕЗА, КАРАКТЕРИЗАЦИЈА И IN VITRO АНТИПРОЛИФЕРАТИВНА АКТИВНОСТ НА НОВИ КОМПЛЕКСИ НА ПЛАТИНА(IV) СО НЕКОИ $O, O^{\prime}$-ДИАЛКИЛ ЕСТЕРИ НА (S,S)-ЕТИЛЕНДИАМИН- $N, N^{\prime}$ ДИ-2-ПРОПАНСКА КИСЕЛИНА ПРОТИВ КЛЕТОЧНИ КУЛТУРИ НА РАК НА ДОЈКА (МDА-МВ-231) И РАК НА ДЕБЕЛОТО ЦРЕВО (НСТ-116 И SW-480)

Синтетизирани се четири нови комплекси на платина(IV) (C1-C4) со бидентатни $N, N^{\prime}$-лиганди прекурзори, $O, O^{\prime}$-диалкилестери $(\mathbf{L} \mathbf{1}-\mathbf{L} 4)$ (алкил = етил, пропил, бутил и пентил) на $(S, S)$ етилендиамин- $N, N^{\prime}$-ди-2-пропанска киселина, $\mathrm{H}_{2}-S, S$-eddp. Комплексите на платина(IV) се карактеризирани со помош на инфрацрвена, ${ }^{1} \mathrm{H}$ и ${ }^{13} \mathrm{C}$ NMR спектроскопија. Цитотоксичноста против култури на туморни клетки на хуман карцином на дојка MDA-MB-231, хуман карцином на дебелото црево НCT-116 и SW-480 се определени со тестот МTT, кој покажа дека колку се поголеми димензиите на лигандот толку е поголема цитотоксичноста.

Клучни зборови: комплекси на платина(IV); $O, O^{\prime}$-диалкилестери; антипролиферативна активност; тест МTT 


\section{INTRODUCTION}

The impressive impact of cisplatin on cancer cells [1-8] had a direct effect on the development of new derivatives with improved pharmaceutical properties. Cisplatin has become the prototype for a unique class of antineoplastic agents [8] although its usage is limited due to nephrotoxicity, emetogenic properties and neurotoxicity $[9,10]$.

There is a growing interest in platinum(IV) complexes due to their high activity and lower toxicity than platinum(II) complexes. Also, platinum(IV) complexes are kinetically more inert than platinum(II) complexes, which allows them to be administered orally, reducing toxicity during platinum-based chemotherapy. Recently, several platinum(IV) complexes containing alkyl esters of edda-type ligands (edda $=$ ion of ethylenediamine$N, N^{\prime}$-diacetic acid) have been tested against different cancer cells [11-18], which indicated these complexes exhibited significantly greater cytotoxicity than cisplatin. These studies also brought to the forefront the possibility for the synthesis of platinum(IV)/alkyl ester complexes.

In this study, the synthesis, characterization and antiproliferative effects of tetrabromido $\left(O, O^{\prime}\right.$-diethyl-( $S, S)$-ethylenediamine- $N, N^{\prime}$-di-2-propanoate)platinum(IV)(C1), tetrabromido $\left(O, O^{\prime}\right.$-dipropyl-(S,S)ethylenediamine- $N, N^{\prime}$-di-2-propanoate)platinum(IV) (C2), tetrabromido $\left(O, O^{\prime}\right.$-dibutyl-( $\left.S, S\right)$-ethylenediamine- $N, N^{\prime}$-di-2-propanoate)platinum(IV)(C3), tetrabromido $\left(O, O^{\prime}\right.$-dipentyl- $(S, S)$-ethylenediamine- $N, N^{\prime}$ di-2-propanoate)platinum(IV) (C4) complexes were explored.

\section{EXPERIMENTAL}

\subsection{Reagents and measurements}

Potassium hexabromidoplatinate(IV) was obtained from Merck and used without further purification. (S,S)-ethylenediamine- $N, N^{\prime}$-di-2-propanoic acid $\left(\mathrm{H}_{2}-\mathrm{S}, \mathrm{S}\right.$-eddp) was prepared [19] and esterified as previously described [20, 21]. Where required, distilled water was used.

Elemental analyses for $\mathrm{C}, \mathrm{H}$ and $\mathrm{N}$ were recorded on a Vario III CHNS Elemental Analyser and water content determined thermogravimetrically. Infrared spectra were recorded by a PerkinElmer Spectrum One FTIR spectrophotometer using the $\mathrm{KBr}$ pellet technique $\left(4000-400 \mathrm{~cm}^{-1}\right)$, and ${ }^{1} \mathrm{H}$ and ${ }^{13} \mathrm{C}$ NMR spectra recorded by a Varian "Gemini 2000" (200 MHz) spectrometer in $\mathrm{CDCl}_{3}$ using tetramethylsilane as the internal standard.

\subsubsection{Preparation of tetrabromido $\left(O, O^{\prime}\right.$-diethyl- (S,S)-ethylenediamine- $N, N^{\prime}$-di-2-propanoate)plat- inum $(I V),\left[\mathrm{PtBr}_{4}(\operatorname{det}-(\mathrm{S}, \mathrm{S})-\mathrm{eddp})\right](\boldsymbol{C l})$}

$\mathrm{K}_{2}\left[\mathrm{PtBr}_{6}\right](0.100 \mathrm{~g}, 0.133 \mathrm{mmol})$ was dissolved in $10 \mathrm{~mL}$ of water in a steam bath and $O, O^{\prime}-$ diethyl-( $S, S)$-ethylenediamine- $N, N^{\prime}$-di-2-propanoate dihydrochloride, det-S,S-eddp $2 \mathrm{HCl},(0.0443 \mathrm{~g}, 0.133$ mmol) was added. The mixture was stirred for $6 \mathrm{~h}$ and an aqueous solution of $\mathrm{LiOH}(0.0064 \mathrm{~g}, 0.266$ $\mathrm{mmol}$ in $10 \mathrm{~mL}$ of water) was introduced. The solution was then filtered and evaporated in a steam bath until a precipitate appeared. After cooling, $\left[\mathrm{PtBr}_{4}(\mathrm{det}-S, S\right.$-eddp) $](\mathbf{C 1})$ as a yellow precipitate, was filtered, washed with ethanol and ether and air-dried. Yield: $0.0599 \mathrm{~g}$ (58.14\%). Anal. Calcd. for $\mathrm{C}_{12} \mathrm{H}_{24} \mathrm{Br}_{4} \mathrm{~N}_{2} \mathrm{O}_{4} \mathrm{Pt}\left(M_{\mathrm{r}}=775.032\right)(\%)$ : C, 18.60 ; $\mathrm{H}, 3.12 ; \mathrm{N}, 3.62 ; \mathrm{H}_{2} \mathrm{O}, 0.00$. Found: C, 19.00; H, 3.22; N, 3.69; $\mathrm{H}_{2} \mathrm{O}, 0.11 \%$. ${ }^{1} \mathrm{H}$ NMR $(200 \mathrm{MHz}$, $\mathrm{CDCl}_{3}, \delta$ ppm): 1.34 (t, $\left.6 \mathrm{H}, \mathrm{CH}_{3}-\mathrm{Et}\right), 1.65(\mathrm{~d}, 6 \mathrm{H}$, $\left.\mathrm{CH}_{3}\right), 2.89$ (m, 4H, $\left.\mathrm{CH}_{2}\right), 4.35$ (q, 2H, CH), 4.92 (q, $4 \mathrm{H}, \mathrm{CH}_{2}$-Et). 6.75-6.90 (broad s, $\left.2 \mathrm{H}, \mathrm{NH}\right) .{ }^{13} \mathrm{C}$ NMR $\left(50 \mathrm{MHz}, \mathrm{CDCl}_{3}, \delta \mathrm{ppm}\right): 13.94\left(\mathrm{CH}_{3}-\mathrm{Et}\right), 15.83$ $\left(\mathrm{CH}_{3}\right), 50.08\left(\mathrm{CH}_{2}\right), 63.50(\mathrm{CH}), 71.24\left(\mathrm{CH}_{2}-\mathrm{Et}\right)$ 172.21 (COO-Et). IR $\left(\mathrm{cm}^{-1}\right): 3128$ (s), $2994(\mathrm{w})$, 1730 (s), 1451 (w), 1322 (m), 1255 (s), 1205 (m), $1106(\mathrm{~m}), 1014(\mathrm{~m}), 745(\mathrm{w})$.

\subsubsection{Preparation of tetrabromido-(O, $O^{\prime}$-dipropyl-} $(S, S)$-ethylenediamine- $N, N^{\prime}$-di-2-propanoate) platinum(IV), $\left[\mathrm{PtBr}_{4}(\mathrm{dpr}-\mathrm{S}, \mathrm{S}\right.$-eddp $\left.)\right]$

$\mathrm{PtBr}_{4}(\mathrm{dpr}-S, S$-eddp) $(\mathbf{C 2})$ was prepared as for $\mathbf{C 1}$, using $O, O^{\prime}$-dipropyl- $(S, S)$-ethylenediamine$N, N^{\prime}$-di-2-propanoate dihydrochloride trihydrate, dpr-S,S-eddp $2 \mathrm{HCl} \cdot 3 \mathrm{H}_{2} \mathrm{O},(0.0553 \mathrm{~g}, 0.133 \mathrm{mmol})$. Yield: $0.0640 \mathrm{~g}$ (59.93\%). Anal. Calcd. for $\mathrm{C}_{14} \mathrm{H}_{28} \mathrm{Br}_{4} \mathrm{~N}_{2} \mathrm{O}_{4} \mathrm{Pt}\left(M_{\mathrm{r}}=803.084\right): \mathrm{C}, 20.94 ; \mathrm{H}$, $3.51 ; \mathrm{N}, 3.49 ; \mathrm{H}_{2} \mathrm{O}, 0.00$. Found: $\mathrm{C}, 21.26 ; \mathrm{H}, 3.52$; $\mathrm{N}, 3.56 ; \mathrm{H}_{2} \mathrm{O}, 0.10 \% .{ }^{1} \mathrm{H}$ NMR $\left(200 \mathrm{MHz}, \mathrm{CDCl}_{3}, \delta\right.$ ppm): 0.97 (t, 6H, $\left.\mathrm{CH}_{3}-n-\mathrm{Pr}\right), 1.23\left(\mathrm{~d}, 6 \mathrm{H}, \mathrm{CH}_{3}\right.$ ), $1.71\left(\mathrm{~m}, 4 \mathrm{H}, \mathrm{CH}_{2}-n-\mathrm{Pr}\right), 3.44$ (m, $\left.4 \mathrm{H}, \mathrm{CH}_{2}\right), 4.23$ (q, $2 \mathrm{H}, \mathrm{CH}), 4.93\left(\mathrm{t}, 4 \mathrm{H}, \mathrm{CH}_{2}-n-\mathrm{Pr}\right), 6.70-6.95$ (broad s, $2 \mathrm{H}, \mathrm{NH}) .{ }^{13} \mathrm{C}$ NMR $\left(50 \mathrm{MHz}, \mathrm{CDCl}_{3}, \delta \mathrm{ppm}\right)$ : $10.31\left(\mathrm{CH}_{3}-n-\mathrm{Pr}\right), 15.94\left(\mathrm{CH}_{3}\right), 21.68\left(\mathrm{CH}_{2}-n-\mathrm{Pr}\right)$, $50.12\left(\mathrm{CH}_{2}\right), 59.86(\mathrm{CH}), 68.97\left(\mathrm{CH}_{2}-n-\mathrm{Pr}\right), 172.36$ (COO- $n$-Pr). IR $\left(\mathrm{cm}^{-1}\right)$ : 3125 (m), 2966 (w), 1733 (s), $1454(\mathrm{w}), 1396(\mathrm{~m}), 1317(\mathrm{~m}), 1255$ (s), 1202 (m), 1107 (s), $1048(\mathrm{~m}), 942(\mathrm{w}), 745(\mathrm{w})$.

\subsubsection{Preparation of tetrabromido- $\left(O, O^{\prime}\right.$-dibutyl- $(S, S)$-ethylenediamine- $N, N^{\prime}$-di-2-propanoate) platinum $(I V),\left[\mathrm{PtBr}_{4}(d b u-S, S-e d d p)\right]$}

$\mathrm{PtBr}_{4}(\mathrm{dbu}-S, S$-eddp) (C3) was prepared as for $\mathbf{C 1}$, using $O, O^{\prime}$-dibutyl- $(S, S)$-ethylenediamine- 
$N, N$ '-di-2-propanoate dihydrochloride trihydrate, dbu-S,S-eddp $\cdot 2 \mathrm{HCl} \cdot 3 \mathrm{H}_{2} \mathrm{O},(0.0589 \mathrm{~g}, 0.133 \mathrm{mmol})$. Yield: $0.0646 \mathrm{~g}$ (58.48\%). Anal. Calcd. for $\mathrm{C}_{16} \mathrm{H}_{32} \mathrm{Br}_{4} \mathrm{~N}_{2} \mathrm{O}_{4} \mathrm{Pt}\left(M_{\mathrm{r}}=831.136\right): \mathrm{C}, 23.12 ; \mathrm{H}, 3.88$; $\mathrm{N}, 3.37 ; \mathrm{H}_{2} \mathrm{O}, 0.00$. Found: $\mathrm{C}, 23.41 ; \mathrm{H}, 3.86 ; \mathrm{N}$, 3.41; $\mathrm{H}_{2} \mathrm{O}, 0.09 \% .{ }^{1} \mathrm{H}$ NMR $\left(200 \mathrm{MHz}, \mathrm{CDCl}_{3}, \delta\right.$ ppm): 0.94 (t, $\left.6 \mathrm{H}, \mathrm{CH}_{3}-n-\mathrm{Bu}\right), 1.21\left(\mathrm{~d}, 6 \mathrm{H}, \mathrm{CH}_{3}\right)$, $1.31\left(\mathrm{~m}, 4 \mathrm{H}, \mathrm{CH}_{2}-n-\mathrm{Bu}\right), 1.68\left(\mathrm{~m}, 4 \mathrm{H}, \mathrm{CH}_{2}-n-\mathrm{Bu}\right)$, $2.87\left(\mathrm{~m}, 4 \mathrm{H}, \mathrm{CH}_{2}\right), 4.25$ (q, 2H, $\left.\mathrm{CH}\right), 4.93(\mathrm{t}, 4 \mathrm{H}$, $\left.\mathrm{CH}_{2}-n-\mathrm{Bu}\right), 6.75-6.90$ (broad s, $\left.2 \mathrm{H}, \mathrm{NH}\right) .{ }^{13} \mathrm{C}$ NMR (50 MHz, $\left.\mathrm{CDCl}_{3}, \delta \mathrm{ppm}\right): 13.61\left(\mathrm{CH}_{3}-n-\mathrm{Bu}\right), 15.84$ $\left(\mathrm{CH}_{3}\right), 19.03\left(\mathrm{CH}_{2}-n-\mathrm{Bu}\right), 30.25\left(\mathrm{CH}_{2}\right), 50.02\left(\mathrm{CH}_{2}-\right.$ $n-\mathrm{Bu}), \quad 59.81 \quad(\mathrm{CH}), \quad 67.32\left(\mathrm{CH}_{2}-n-\mathrm{Bu}\right), 172.37$ (COO-n-Bu). IR $\left(\mathrm{cm}^{-1}\right)$ : 3119 (m), 2961 (m), 2872 (w), 1733 (s), 1455 (m), 1396 (m), 1316 (m), 1255 (m), 1201 (m), 1107 (m), $1048(\mathrm{~m}), 943(\mathrm{w}), 745(\mathrm{w})$.

\subsubsection{Preparation of tetrabromido-( $O, O^{\prime}$-dipentyl- $(S, S)$-ethylenediamine- $N, N^{\prime}$-di-2-propanoate) platinum $(I V),\left[\mathrm{PtBr}_{4}(d p e-S, S\right.$-eddp $\left.)\right]$}

$\mathrm{PtBr}_{4}(\mathrm{dpe}-S, S$-eddp) (C4) was prepared as for $\mathbf{C 1}$, using $O, O^{\prime}$-dipentyl- $(S, S)$-ethylenediamine$N, N^{\prime}$-di-2-propanoate dihydrochloride dihydrate, dpe- $S, S$-eddp $2 \mathrm{HCl} \cdot 2 \mathrm{H}_{2} \mathrm{O},(0.0603 \mathrm{~g}, 0.133 \mathrm{mmol})$. Yield: $0.0595 \mathrm{~g}(52.11 \%)$. Anal. Calcd. for $\mathrm{C}_{18} \mathrm{H}_{36} \mathrm{Br}_{4} \mathrm{~N}_{2} \mathrm{O}_{4} \mathrm{Pt}\left(M_{\mathrm{r}}=859.188\right): \mathrm{C}, 26.16 ; \mathrm{H}$, 4.22; N, 3.26; $\mathrm{H}_{2} \mathrm{O}, 0.00$. Found: $\mathrm{C}, 26.39 ; \mathrm{H}, 4.29$; $\mathrm{N}, 3.18 ; \mathrm{H}_{2} \mathrm{O}, 0.08 \% .{ }^{1} \mathrm{H}$ NMR $\left(200 \mathrm{MHz}, \mathrm{CDCl}_{3}\right.$, $\delta$ ppm): 0.91 (t, 6H, $\left.\mathrm{CH}_{3}-n-\mathrm{Pe}\right), 1.19\left(\mathrm{~d}, 6 \mathrm{H}, \mathrm{CH}_{3}\right)$, 1.29 (m, 4H, $\left.\mathrm{CH}_{2}-n-\mathrm{Pe}\right), 1.41$ (m, 4H, $\left.\mathrm{CH}_{2}-n-\mathrm{Pe}\right)$, $1.59\left(\mathrm{~m}, 4 \mathrm{H}, \mathrm{CH}_{2}-n-\mathrm{Pe}\right), 2.87\left(\mathrm{~m}, 4 \mathrm{H}, \mathrm{CH}_{2}\right), 3.74$ (q, 2H, CH), 4.24 (t, 4H, $\left.\mathrm{CH}_{2}-n-\mathrm{Pe}\right), 6.90-7.25$ (broad s, 2H, NH). ${ }^{13} \mathrm{C}$ NMR $\left(50 \mathrm{MHz}, \mathrm{CDCl}_{3}, \delta\right.$ ppm): $13.94\left(\mathrm{CH}_{3}-n-\mathrm{Pe}\right), 15.80\left(\mathrm{CH}_{3}\right), 22.23\left(\mathrm{CH}_{2}-\right.$ $n$-Pe), $27.91\left(\mathrm{CH}_{2}-n-\mathrm{Pe}\right), 40.5\left(\mathrm{CH}_{2}\right), 59.5\left(\mathrm{CH}_{2}-n-\right.$ $\mathrm{Pe}), 60.1(\mathrm{CH}), 67.3\left(\mathrm{CH}_{2}-n-\mathrm{Pe}\right), 172.1(\mathrm{COO}-n-$ Pe). IR ( $\left.\mathrm{cm}^{-1}\right): 3130(\mathrm{~m}), 2958(\mathrm{~s}), 2931$ (s), 2865 (m), 1735 (s), $1461(\mathrm{~m}), 1389$ (w), 1315 (m), 1255 (s), $1196(\mathrm{~s}), 1110(\mathrm{~m}), 1055(\mathrm{~m}), 966(\mathrm{w}), 748(\mathrm{w})$.

\subsection{In vitro studies}

\subsubsection{Cell preparation and culturing}

Cancer cell lines were propagated and maintained in DMEM (Dulbecco's Modified Eagle Medium; Gibco, Invitrogen, Carlsbad, CA, USA) supplemented with $10 \%$ foetal bovine serum (PAA, Pasching, Austria) and antibiotics (100 IU/ml penicillin and $100 \mu \mathrm{g} / \mathrm{ml}$ streptomycin) at $5 \% \mathrm{CO}_{2}$ and $37^{\circ} \mathrm{C}$ in a humidified atmosphere. MDA-MB231 (breast cancer isolated from metastatic tissue), HCT-116 and SW-480 (colon cancer cell lines isolated from primary tumour tissue) were obtained from the American Tissue Culture Collection (Ma- nassas, VA, USA). Cells were grown in $75 \mathrm{~cm}^{2}$ culture flasks and after five passages, all tested cell lines were seeded into 96-well plate.

\subsubsection{Cell viability assay (MTT assay)}

After reaching the cell confluence of about 70 to $80 \%$ all cell viability studies were performed simultaneously. MDA-MB-231, HCT-116 and SW-480 cells were seeded in a 96-well plate $\left(10^{4}\right.$ cells per well). Cells were allowed to adhere $24 \mathrm{~h}$ and then, cells were treated with $100 \mu \mathrm{l}$ of each concentration $(0.1,1,10,50,100$ and $500 \mu \mathrm{M})$ for each compound. Cells untreated with investigated compounds served as the control, and have only been supplemented by replacement of growing medium. After 24 and $72 \mathrm{~h}$ of treatment, cell viability was determined by MTT assay according to the manufacturers' protocol. Briefly, medium with tested substances and control medium were replaced with $100 \mu \mathrm{l}$ DMEM and $25 \mu \mathrm{l}$ of $5 \mathrm{mg} / \mathrm{ml}$ MTT (3-[4,5-dimethylthiazol-2-yl]-2,5-diphenyltetrazolium bromide) dissolved in PBS and the 96well plates incubated at $37^{\circ} \mathrm{C}$ in $5 \% \mathrm{CO}_{2}$ for $2 \mathrm{~h}$. After incubation, MTT medium was replaced with $150 \mu \mathrm{l}$ of DMSO, and absorbance of coloured solution of formazan product was measured at $550 \mathrm{~nm}$. Cell proliferation was calculated as the absorbance of the treated group divided by the absorbance of control group multiplied by 100 to yield percent proliferation [22].

\subsection{Statistical analysis}

The data were expressed as the mean \pm standard error (SE). Biological activity was the result of one individual experiment performed in triplicate for each dose. The magnitude of correlation between variables was calculated using the SPSS statistical software package (SPSS for Windows, ver. 17, 2008, Chicago, IL, USA). The effect of each extract was expressed as the $\mathrm{IC}_{50}$ (inhibitory dose which inhibit $50 \%$ growth cells) and by the maximal effect magnitude for exposed cells. The $\mathrm{IC}_{50}$ values were calculated from the dose curves using CalcuSyn software for Windows, ver. 2.0 (Biosoft, Cambridge, UK).

\section{RESULTS AND DISCUSSION}

\subsection{Synthesis and characterization}

$\mathrm{PtBr}_{4}\left(\mathrm{R}_{2}-S, S\right.$-eddp) complexes were synthesized by mixing an aqueous solution of $\mathrm{K}_{2}\left[\mathrm{PtBr}_{6}\right]$ and the corresponding esters (Scheme 1). The resulting 
complexes were soluble in chloroform and dimethylsulfoxide, but not in water. The results of microanalysis confirmed the predicted content of the isolated complexes.<smiles>[R20]C(=O)[C@H](C)NCCN[C@H](C)C([R6])=O</smiles>

Scheme 1. The preparation of the $\left[\mathrm{PtBr}_{4}\left(\mathrm{R}_{2}-S, S\right.\right.$-eddp) $]$ complexes

The IR spectra showed specific $v(\mathrm{C}=\mathrm{O}) \mathrm{ab}$ sorption bands at 1730, 1733,1733, $1734 \mathrm{~cm}^{-1}$ (strong), (typical absorption for aliphatic esters), $v(\mathrm{C}-\mathrm{O})$ bands at $1205,1202,1201,1201 \mathrm{~cm}^{-1}$ and $v\left(\mathrm{CH}_{3}\right)$ bands at 2968, 2967, 2961, $2961 \mathrm{~cm}^{-1}$. The infrared spectra of the complexes confirmed the expected $N-N$ coordination of the ligands to the platinum(IV) ion. Coordination via nitrogen ligand atoms could be proven by the presence of bands for secondary amino groups $\left(3128 \mathrm{~cm}^{-1}\right.$ for $\mathbf{C 1}, 3125$ $\mathrm{cm}^{-1}$ for $\mathbf{C 2}, 3119 \mathrm{~cm}^{-1}$ for $\mathbf{C 3}$, and 3118 for $\mathbf{C 4}$ ) and absence of the protonated secondary ammonium group, found in the IR spectra of the $\mathrm{R}_{2}-S$, $S$-eddp precursors $\left(3437 \mathrm{~cm}^{-1}\right.$ for $\mathbf{C 1}, 3461 \mathrm{~cm}^{-1}$ for C2, $3461 \mathrm{~cm}^{-1}$ for $\mathbf{C 3}$ and $3462 \mathrm{~cm}^{-1}$ for C4) [20, 21].

The position and number of signals in the ${ }^{1} \mathrm{H}$ and ${ }^{13} \mathrm{C}$ NMR spectra for the isolated complexes confirmed the coordination of the esters to the platinum(IV) ion. In the ${ }^{1} \mathrm{H}$ NMR spectra of $\mathbf{C 1}-$ C4, hydrogen atoms of secondary amino groups showed broad signals at 6.70-7.25 ppm. Coordination-induced shifts in the C1-C4 spectra (of up to $0.9 \mathrm{ppm}$ ) were attributed to the signals of the $\mathrm{CH}_{2}$ protons of the ethylenediamine bridge which implied nitrogen coordination. In the ${ }^{13} \mathrm{C}$ NMR spectra, ester carbon atom resonances were found at the expected position ( $170 \mathrm{ppm})$ for all compounds, which indicated that oxygen was not a ligating atom.

\subsection{Antiproliferative activity}

After cell seeding in standard DMEM medium, cells were exposed to different drug con- centrations for 24 and $72 \mathrm{~h}$ at $37^{\circ} \mathrm{C}$ and MTT results are presented by $\mathrm{IC}_{50}$ values shown in Table 1. By comparing the ligand antiproliferative effect especially on MDA-MB-231 cells (as well as on HCT-116 and SW-480 cells), the $\mathrm{IC}_{50}$ values and MTT values indicated that cytotoxicity increased as the size of the ligand increased (ethyl, L1 $<$ propyl, L2 < < buthyl, L3 < pentyl, L4) though the sensitivity differed (SW-480 < HCT-116 < MDA$\mathrm{MB}-231)$. The $\mathrm{IC}_{50}$ values indicated that MDAMB-231 cells were more sensitive to investigated ligands than HCT-116 and SW-480 cells because $\mathrm{IC}_{50}$ for MDA-MB-231 for propyl and butyl ligands indicated values lower than $500 \mu \mathrm{M}$, while $\mathrm{IC}_{50}$ for investigated colon cancer cell lines were greater than $500 \mu \mathrm{M}$ for all ligands with exception of impact of L4 on HCT-116.

The complexes showed a similar trend for antiproliferative activity, i.e. the larger the complex, the greater the antiproliferative effect $(\mathbf{C 1}<\mathbf{C 2}<$ C3 $<$ C4). These data suggested activity was related to the $\mathrm{R}$ substituent in the $(S, S)-\mathrm{R}_{2}$ eddip, which was supported by published data indicating that increasing the number of $\mathrm{C}$ atoms in the chain increases cytotoxic activity [23]. By comparing the effects, the data indicated the complexes were not significantly more cytotoxic than the corresponding ligands, with the exception of $\mathbf{C 4}$ complex activity on MDA-MB-231 cells (where complex was more cytotoxic), and $\mathbf{C 3}$ and $\mathbf{C 4}$ complexes on SW-480 cells (Table 1). 
T a ble 1

$I C_{50}$ values $(\mu M)$ for ligands and complexes on MDA-MB-231, HCT-116 and SW-480 cells after 24 and 72 of exposure

\begin{tabular}{crrrrrrrr}
\hline \hline MDA-MB-231 & $24 \mathrm{~h}$ & $72 \mathrm{~h}$ & HCT-116 & $24 \mathrm{~h}$ & $72 \mathrm{~h}$ & $\mathrm{SW}-480$ & $24 \mathrm{~h}$ & $72 \mathrm{~h}$ \\
\hline $\mathbf{L 1}$ & $>500$ & $>500$ & $\mathbf{L 1}$ & $>500$ & $>500$ & $\mathbf{L 1}$ & $>500$ & $>500$ \\
$\mathbf{L 2}$ & 272 & $>500$ & $\mathbf{L 2}$ & $>500$ & $>500$ & $\mathbf{L 2}$ & $>500$ & 200 \\
$\mathbf{L 3}$ & $>500$ & 158 & $\mathbf{L 3}$ & $>500$ & $>500$ & $\mathbf{L 3}$ & $>500$ & $>500$ \\
$\mathbf{L 4}$ & 355 & 235 & $\mathbf{L 4}$ & 225 & 74 & $\mathbf{L 4}$ & $>500$ & $>500$ \\
$\mathbf{C 1}$ & $>500$ & $>500$ & $\mathbf{C 1}$ & $>500$ & $>500$ & $\mathbf{C 1}$ & $>500$ & $>500$ \\
$\mathbf{C 2}$ & $>500$ & $>500$ & $\mathbf{C 2}$ & $>500$ & $>500$ & $\mathbf{C 2}$ & $>500$ & $>500$ \\
$\mathbf{C 3}$ & $>500$ & $>500$ & $\mathbf{C 3}$ & $>500$ & $>500$ & $\mathbf{C 3}$ & 344 & 58 \\
$\mathbf{C 4}$ & 218 & 192 & $\mathbf{C 4}$ & 225 & 363 & $\mathbf{C 4}$ & 57 & 3 \\
\hline \hline
\end{tabular}

\section{CONCLUSIONS}

Four novel platinum(IV) complexes (C1-C4) were synthesized and characterized by IR, ${ }^{1} \mathrm{H}$ NMR, ${ }^{13} \mathrm{C}$ NMR spectroscopy, and elemental analysis. Antiproliferative effect of the investigated substances on cell lines of human colon (HCT-116 and SW-480) and breast (MDA-MB-231) cancer showed higher antiproliferative effect compared to the appropriate ligands, what is in agreement with our expectations that these complexes have moderate to high antiproliferative impact. As with ligands also with complexes, with increasing the size of investigated drug, i.e. with increasing the number of $\mathrm{C}$-atoms in ligand side chains, the antiproliferative effect increases. By comparing of the obtained results we notice that the effect of tested substances is usually not acute, i.e. a significantly higher antiproliferative effect is observed after $72 \mathrm{~h}$ than after $24 \mathrm{~h}$ from treatment. Regarding the moderate antiproliferative activity of ligands, we conclude that the highest effect is achieved on MDA-MB-231 cells, while complexes showed the highest impact on SW-480 cells. As we discussed above, this effect is particularly obvious with complex $\mathbf{C 4}$ (with pentyl ligand) with $\mathrm{IC}_{50}$ values of 57 $\mu \mathrm{M}$ for $24 \mathrm{~h}$ and even of $3 \mu \mathrm{M}$ for $72 \mathrm{~h}$ from treatment on SW-480 cell line. Such a significant anti-tumor in vitro activity shows once again that the $\mathrm{Pt}(\mathrm{IV})$ complexes are suitable for the synthesis of novel chemotherapeutic products with high antiproliferative effects on tumor tissue providing a low toxicity for healthy cells.

Acknowledgements: The authors are grateful to the Ministry of Education, Science and Technological Development of the Republic of Serbia for financial support (Grant Nos. 172016 and III41010).

\section{REFERENCES}

[1] B. Rosenberg, L. VanCamp, T. Krigas, Inhibition of cell division in Escherichia coli by electrolysis production from a platinum electrode. Nature, 205, 698-699 (1965).
[2] Y. Kidani, K. Iganaki, M. Ligo, A. Hoshi, K. Kuretani, Antitumor activity of 1,2-diaminocyclohexaneplatinum complexes against Sarcoma-180 ascites form. J. Med. Chem., 21, 1315-1318 (1978).

[3] K. R Harrap, Preclinical studies identifying carboplatin as a viable cisplatin alternative. Cancer Treat. Rev., 12, 21-33 (1985).

[4] R. J. Knox, F. Friedlos, D. A. Lyndall, J. J. Roberts, Mechanism of Cytotoxicity of Anticancer Platinum Drugs: Evidence That cis-Diamminedichloroplatinum(II) and cis-Diammine-(1,1-cyclobutanedicarboxylato)platinum(II) Differ Only in the Kinetics of Their Interaction with DNA. Cancer Res., 46, 1972-1979 (1986).

[5] Z. H. Ziddik, Cisplatin: mode of cytotoxic action and molecular basis of resistance. Oncogene, 22, 7265-7279 (2003).

[6] E. Wong, C. M. Giandomenico, Current Status of Platinum-Based Drugs. Chem. Rev., 99, 2451-2466 (1999).

[7] U. Kalinowska-Lis, J. Ochocki, K. MatlawskaWasowska, Trans geometry in platinum antitumor complexes. Coord. Chem. Rev. 252, 1328-1345 (2008).

[8] B. Lippert, In Cisplatin: Chemistry and Biochemistry of a Leading Anticancer Drug, Wiley-VCH, Weinheim, Germany, 1999.

[9] O. Rixe, W. Ortuzar, M. Alvarez, R. Parker, E. Reed, K. Paull, T. Fojo, Oxaliplatin, tetraplatin, cisplatin, and carboplatin: Spectrum of activity in drug-resistant cell lines and in the cell lines of the National Cancer Institute's anticancer drug screen panel. Biochem. Pharmacol., 52, 1855-1865 (1996).

[10] D. Machover, E. Diaz-Rubio, A. de Granmont, A. Schif, J-J. Gastiaburu, S. Brienza, M. Itzhaki, G. Metzer, D. N'Daw, J. Vignoud, A. Abad, E. François, E. Gamelin, M. Marty, J. Sastre, J-F. Seitz, M. Ychou, Two consecutive phase II studies of oxaliplatin (L-OHP) for treatment of patients with advanced colorectal carcinoma who were resistant to previous treatment with fluoropyrimidines. Ann. Oncol., 7, 95-98 (1996).

[11] T. J. Sabo, G. N. Kaluđerović, S. R. Grgurić-Šipka, F.W. Heinemann, S. R. Trifunović, Complex compounds of platinum(IV) and $O, O$-dialkylethylenediamine- $N, N^{\prime}$-di3-propanoate ligands. A structural evidence for geometry of hydrolytic product of some esters. Inorg. Chem. Comm., 7, 241-244 (2004). 
[12] G. N. Kaluđerović, V. M. Đinović, Z. D. Juranić, T. P. Stanojković, T. J. Sabo, Activity of some platinum(II/IV) complexes with $O, O-n$-butyl- and $O, O-n$ pentyl-ethylenediamine- $N, N^{\prime}$-di-3-propanoate and halogeno ligands against HeLa and K562 cell lines and human PBMC. J. Inorg. Biochem., 99, 488-496 (2005).

[13] G. N. Kaluđerović, Đ. Miljković, M. Momčilović, V. M. Đinović, M. Mostarica-Stojković, T. J. Sabo, V. Trajković, Novel platinum(IV) complexes induce rapid tumor cell death in vitro. Int. J. Cancer, 116, 479-486 (2005).

[14] G. N. Kaluđerović, H. Schmidt, S. Schwieger, Ch. Wagner, R Paschke, A. Dietrich, T. Mueller, D. Steinborn, Platinum(IV) complexes with ethylenediamine- $N, N^{\prime}-$ diacetate diester $\left(\mathrm{R}_{2} \mathrm{ed}_{\mathrm{d}} \mathrm{a}\right)$ ligands: Synthesis, characterization and in vitro antitumoral activity. Inorg. Chim. Acta, 361, 1395-1404 (2008).

[15] B. B. Krajčinović, G. N. Kaluđerović, D. Steinborn, H. Schmidt, Ch. Wagner, Ž. Žižak, Z. D. Juranić, S. R. Trifunović, T. J. Sabo, Synthesis and in vitro antitumoral activity of novel $O, O^{\prime}$-di-2-alkyl-(S,S)-ethylenediamine- $N, N^{\prime}$ di-2-propanoate ligands and corresponding platinum(II/IV) complexes. J. Inorg. Biochem., 102, 892-900 (2008).

[16] G. N. Kaluđerović, T. M. Vasiljević, M. D. Laušević, A. S. Gaballa, T. J. Sabo, Electrospray mass spectrometric studies of a potential antitumor drug and its analogous platinum(II) and platinum(IV) complexes with the ethylenediamine- $N, N^{\prime}$-di-3-propanoato ligand and its dibutyl ester. Monatsh. Chem., 140, 553-557 (2009).

[17] G. N. Kaluđerović, H. Kommera, S. Schwieger, H. Schmidt, A. Paethanom, M. Kunze, R. Paschke, D. Steinborn, Synthesis, characterization, in vitro antitumoral investigations and interaction with plasmid pBR322 DNA of $R_{2 \mathrm{e}} \mathrm{ddp}$-platinum(IV) complexes $(\mathrm{R}=$ Et, n-Pr). Dalton Trans., 10720-10726 (2009).

[18] J. M. Lazić, Lj. Vučićević, S. Grgurić-Šipka, K. Janjetović, G. N. Kaluđerović, M. Misirkić, M. Gruden-
Pavlović, D. Popović, R. Paschke, V. Trajković, T. J. Sabo, Synthesis and in vitro anticancer activity of octahedral platinum(IV) complexes with cyclohexylfunctionalized ethylenediamine-N,N'-diacetate-type ligands. Chem. Med. Chem., 5, 881-889 (2010).

[19] L. N. Schoenberg, D. W. Cooke, C. F. Liu, Nuclear magnetic resonance determination of the absolute configuration of complexes of cobalt(III) with asymmetric tetradentate ligands. Inorg. Chem., 7, 2386-2393 (1968).

[20] M. Z. Stanković, G. P. Radić, V. V. Glođović, I. D. Radojević, O. D. Stefanović, Lj. R. Čomić, O. R. Klisurić, V. M. Đinović, S. R. Trifunović, Stereospecific ligands and their complexes, IX: Synthesis, characterization and antimicrobial activity of ethyl esters of $(S, S)$ ethylenediamine- $N, N^{\prime}$-di-2-propanoic and (S,S)-ethylenediamine- $N, N$ '-di-2-(3-methyl)-butanoic acids and corresponding platinum(IV) complexes: Crystal structure of tetrachloride- $\left(O, O^{\prime}\right.$-diethyl-( $\left.S, S\right)$-ethylenediamine- $N, N^{\prime}$-di-2propanoato)-platinum(IV), $\left[\mathrm{PtCl}_{4}(\mathrm{det}-\mathrm{S}, \mathrm{S}\right.$-eddp) $]$. Polyhedron, 30, 2203-2209 (2011).

[21] G. P. Vasić, V. V. Glođović, I. D. Radojević, O. D. Stefanović, Lj. R. Čomić, V. M. Đinović, S. R. Trifunović, Stereospecific ligands and their complexes. V: Synthesis, characterization and antimicrobial activity of palladium(II) complexes with some alkyl esters of $(S, S)$ ethylenediamine- $N, N^{\prime}$-di-2-propanoic acid. Inorg. Chim. Acta, 363, 3606-3610 (2010).

[22] T. Mosmann, Rapid colorimetric assay for cellular growth and survival: Application to proliferation and cytotoxicity assays. J. Immunol. Meth., 65, 55-63 (1983).

[23] B. B. Zmejkovski, G. N. Kaluđerović, S. Gómez-Ruiz, Ž. Žižak, D. Steinborn, H. Schmidt, R. Paschke, Z. D. Juranić, T. J. Sabo, Palladium(II) complexes with $\mathrm{R}_{2}$ edda-derived ligands, Part II, Synthesis, characterization and in vitro antitumoral studies of $\mathrm{R}_{2}$ eddip esters and palladium(II) complexes. Eur. J. Med. Chem., 44, 3452-3458 (2009). 